\title{
Methodological Issues of Economic Analysis at Various Stages of Reorganisation of Legal Entities
}

\author{
Bezvidnaya O.S. a \\ Lopukhova N.V.b \\ ab Kazan Federal University, Institute of Management, Economics and Finance, Kazan, 420008, Russia \\ Email:nvlop@mail.ru
}

Doi:10.5901/mjss.2015.v6n1s3p370

\section{Abstract}

The article comprises a definition of methodological features of economic analysis at various stages of reorganisation of legal entities. The paper used the abstract-logical method. The basic stages of reorganisation of legal entities: preliminary, preparatory, registration, final. The main directions of economic analysis for each stage of reorganisation, its goals, objectives, information base and methodological issues were identified and justified. The basic stages of reorganisation of legal entities related to certain management decisions, control and analytical work. The main features of analytical work at various stages of reorganisation were defined. There will be a choice of optimum management decisions based on results of analytical work when deciding on reorganisation, optimum forms of its implementation and process of its implementation.

Keywords: restructuring, reorganisation stages, economic analysis, financial model of the effects of the reorganisation

\section{Introduction}

Russian legislation stipulates five basic forms of reorganisation of legal entities: consolidation, merger, separation, division and transformation [1]. A feature of the process of reorganisation of organisations is that the transfer of rights and obligations of the legal entity is made in full, without any exemptions and exceptions under the act of transfer or separation balance sheet. Reorganisation is an economic process that causes a termination of the legal entity, with the transfer of all its rights and obligations to one or more new legal entities, or the emergence of a new legal entity with a direct link to it and the rights and obligations of the legal entity continue to exist [2, 3].

In our opinion, it is appropriate to present a process of reorganisation in the form of successive stages (Figure 1), each of which includes relevant activities.

In scientific literature, there are various approaches to the separation of the process of reorganisation into separate stages $[4,5,6]$. So, from the point of view of personnel management during reorganisation, it is appropriate to highlight the following stages: creating the image of a "desired future", planning the reorganisation process, the start of changes, support for reorganisation, mobilisation, and update [7].

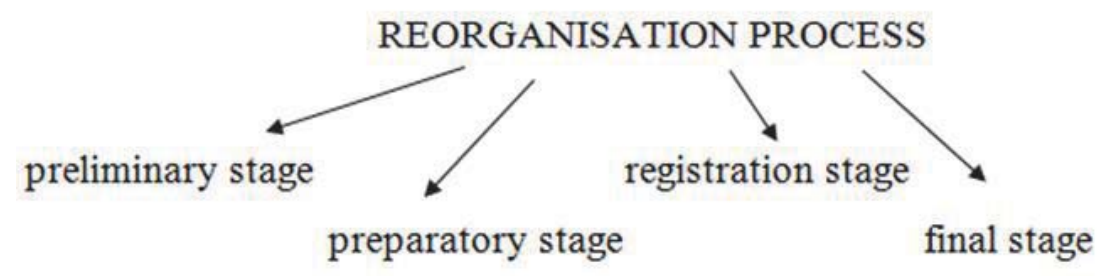

Fig.1. Sequence of stages in the process of reorganisation.

The legal procedure for reorganisation consists of the following stages: decision on the reorganisation, notice to the registering authority to initiate the procedure of reorganisation, sending Unified State Register of Legal Entities incorporation records starting the reorganisation procedure, the publication of the notice of the procedure to the media, written notice to creditors, the composition of the separation balance sheet or the act of transfer, cancellation of 
registration with the tax office and the old legal entities and registration of new and closing the old settlement accounts and registration with the registering body regarding the newly created legal entities and deregistration of that which ceases to exist, and other necessary actions [8].

However, from the point of view of targeting the economic challenges facing the organisation at any given point in time, there is a need for various management decisions, and the stages we have proposed are optimal $[9,10]$.

\section{Theory}

The preliminary stage includes activities to prepare for the adoption of decisions on reorganisation and a meeting of members (shareholders) of the company. The preliminary stage ends with holding a general meeting of members (shareholders) of the company about the reorganisation of the company and decision to reorganise.

At the preparatory stage, participants (shareholders) are redeemed of shares in relation to their exit as the owners of the company, the tax authority is notified, work with creditors takes place, and there is an inventory of assets and liabilities of the reorganised company, along with preparation of the separation balance sheet. The preparatory phase ends with the compilation of the separation balance sheet date or transfer act. The registration stage consists of the state registration procedure of the reorganisation. At the final stage of reorganisation, the final preparation is made of financial statements, preparation of transfer certificates of assets and liabilities, and the preparation of introductory accounting. The final stage of ends with the approval date of the introductory accounting.

Each of the selected stages is associated with certain management decisions, control and analytical work [11, 12, 19]. Thus, the reorganisation of enterprises is a complex process in which there is a need for analysis. The company's activities, both before the reorganisation and after, are aimed at obtaining a specific result, depending on the resources available to the organisation, the extent of risk management, and the state of the external and internal environment of the firm. As a result of the influence of many factors of various characters, the results are often different from those projected. In this connection, a number of issues appear that without analysis are quite difficult to resolve: reasons for this situation, the development of solutions to address shortcomings, and selecting the optimum option.

In our view, analysis of economic activity is an important stage in the decision of any administrative decision, and it acquires special importance in the preparation and implementation of reorganisation $[13,18]$. The essence of the economic analysis is integrated study of the organisation in accordance with its objectives, but at the same time, as a result of the analysis, new information appears, which is later used in the management of the company.

In general terms, any method of analysis is methodological advice on analytical studies and includes the following stages:

- formulation of the main goals and objectives of the analysis, and the definition of objects and users of the analysis;

- compilation of indicators that will be analysed;

- identification of sources of data for analysis;

- selection of methods and techniques to be used for analytical processing of information.

It should be noted that the choice whichever methods of analysis will depend on the purpose, depth of analysis, object of research and technical possibilities.

As already noted, the reorganisation process should be presented in the form of successive stages, including individual measures, namely: preliminary, preparatory, registration, final.

At the preliminary stage, in our opinion, it is necessary to conduct a study and analysis of the desirability and feasibility of the reorganisation, and select the optimum form of reorganisation. The success of the reorganisation proceedings depends on the state of the company's equipment, the availability of modern production technologies, competitive products, the reality of covering debt, and the possibility of reorganisation of the production process and business management system. In our opinion, at this stage, you should use methods and techniques of management analysis designed to provide administrative staff organizing the information needed to manage and monitor the activities of the organisation. Management analysis is mainly associated with the study of primary information about production and costs.

The main objectives of the analysis at this stage include:

- definition of the organisational and technical capacities of the reorganised company, product competitiveness, and the state of the market;

- analysis of the possibilities of increasing the volume of production and sales, and accelerating sales of 
products through reorganisation;

- assessment of the possible results of the reorganised production enterprises, forecasting indicators such as costs, sales and profits;

- decision on the reorganisation and determination of the optimum form of reorganisation;

- development of a strategy of cost management to reorganise businesses by deviations, cost centres and responsibility.

At this stage, it is obligatory to pay attention to the analysis of the input during the reorganisation of changes and assess their effectiveness in terms of taxation. The main objective here is to determine how best to implement the planned changes, which can be solved with the use of elements of strategic tax planning.

In our opinion, at the preliminary stage of reorganisation, development of a unified methodology for assessing the capabilities and effectiveness of the reorganisation is not expedient. The main reasons for the reorganisation may be:

- forced reorganisation;

- improvement of the management structure of the enterprise;

- allocation of structural units and individual process units in the independent legal entities;

- optimisation of tax payments;

- disagreements between the founders and others.

Depending on the reasons for the reorganisation, the methodological approaches to internal analysis will vary.

In the preparatory phase of reorganisation, depending on the chosen form, compilation of the transfer certificate or separation balance sheet is carried out. This stage ends with the presentation of necessary documents to the registration authorities.

This stage is characterized by active work of the reorganised company with debtors, creditors, debt reconciliation with suppliers and customers, and negotiation of debt payments to the budget and extrabudgetary funds. During this period, disputed debts may be experienced, for example, non-recognition of debt by debtors or creditors presenting increased requirements, as well as the detection of errors in accounting as unpresented invoices, or other operations not carried out.

In our opinion, at this stage, analysis of the financial condition is particularly important, which is characterized by providing a company the financial resources necessary for normal functioning of the enterprise, the feasibility and effectiveness of deployment and use, and solvency and financial stability of the organisation.

As a rule, two types of financial analysis are distinguished: internal and external.

Internal financial analysis is performed by services of a company, and its main purpose is to ensure the normal operation of the business, a profit, and the exclusion of bankruptcy. The information base of such analysis is quite wide and includes any information circulating within the enterprise and needed to make management decisions. In the context of the reorganisation, such analysis is required in the preparation of the transfer certificate or separation balance sheet to assess the current and future financial condition of the reorganised organisation.

External analysis is carried out by investors, creditors, and regulatory authorities on the basis of published reports. Its purpose is the opportunity for profitable investment with maximum profits and minimal risk. In our opinion, in the process of reorganisation, the main users of the information obtained in the course of the financial analysis are not only the owners, but also the creditors of the reorganised enterprise.

In accordance with the Civil Code of the Russian Federation, it is necessary to notify all creditors of the reorganised company about the upcoming reorganisation. Creditors of the organisation have the right to require early termination or performance of the obligations of the Company, not later than thirty days from the date of such notice or publication of the notice of the reorganisation. When deciding on early claims on repayment of obligations of the reorganised companies, lenders require information on the financial status of the reorganised enterprise.

Economic literature identifies two main approaches to the analysis of the financial condition of the organisation [14]. Depending on the goals set, as well as informational, temporary, technical and other factors released, rapid analysis of financial conditions and detailed analysis of financial conditions are separated. The main purpose of rapid analysis based on financial statements is clear and simple evaluation of the financial prosperity and development dynamics of the economic entity. Rapid analysis can end with withdrawal of the need for more in-depth and detailed analysis of the financial position and results.

In general, the programme of in-depth analysis of financial and economic activity of the enterprise, in addition to prior review of the economic and financial situation of the organisation, includes the following sections: assessment of property, liquidity, financial stability, business activity, and profitability of the commercial organisation in the securities market $[15,16,17]$. 
In our view, for initial assessment of the financial situation of the reorganised enterprise, relative liquidity and financial stability should be used. At the same time, comparison with normative values used for the particular industry and benchmarks of the reorganised company should be used. Such information will enable creditors of reorganised entities to decide on the expediency of early requirements for return of debt.

\section{Results}

In this way, the ratio of the stages of the process of reorganisation with the tools of economic analysis used in each of them is represented in Table 1.

Table 1. Features of economic analysis at each stage of the reorganisation process

\begin{tabular}{|c|c|c|}
\hline $\begin{array}{l}\text { Reorganisation } \\
\text { process stage }\end{array}$ & $\begin{array}{l}\text { Characterisation of the reorganisation } \\
\text { process stage }\end{array}$ & $\begin{array}{l}\text { Methods and economic analysis used in each } \\
\text { stage }\end{array}$ \\
\hline Preliminary stage & $\begin{array}{l}\text { Preparations for the adoption of decisions } \\
\text { on reorganisation, and of meeting } \\
\text { participants (shareholders) staging the } \\
\text { general meeting and the decision on } \\
\text { reorganisation. }\end{array}$ & $\begin{array}{l}\text { Study and analysis of the desirability and } \\
\text { feasibility of reorganisation, the choice of } \\
\text { optimum form of reorganisation, the use of } \\
\text { methods and techniques of management } \\
\text { analysis necessary for the management } \\
\text { organisation of information needed to manage } \\
\text { and monitoring activities of the organisation. } \\
\text { Analysis of the input during the reorganisation of } \\
\text { changes and evaluation of their effectiveness in } \\
\text { terms of taxation, and definition of the most } \\
\text { efficient ways of implementing the planned } \\
\text { changes, which can be solved with the use of } \\
\text { elements of strategic tax planning. }\end{array}$ \\
\hline Preparatory & $\begin{array}{l}\text { Redemption of the participants } \\
\text { (shareholders) of shares in connection with } \\
\text { their exit of the proprietors of the company, } \\
\text { notification to the tax authorities, work with } \\
\text { creditors on inventory of property and } \\
\text { liabilities of the reorganised company and } \\
\text { preparation of the separation balance } \\
\text { sheet. }\end{array}$ & $\begin{array}{l}\text { Analysis of the financial condition, which is } \\
\text { characterized by providing a company the } \\
\text { financial resources necessary for normal } \\
\text { functioning of the enterprise, the feasibility and } \\
\text { effectiveness of deployment and use, and } \\
\text { solvency and financial stability of the } \\
\text { organisation. } \\
\text { Comparison with normative values used for the } \\
\text { particular industry and benchmarks of the } \\
\text { reorganised company. }\end{array}$ \\
\hline Registration & $\begin{array}{l}\text { Procedure of state registration of } \\
\text { reorganisation. }\end{array}$ & $\begin{array}{l}\text { Compliance with state deadlines and additional } \\
\text { analytical procedures are not stipulated. }\end{array}$ \\
\hline Final & $\begin{array}{l}\text { Preparation of financial statements, } \\
\text { compilation of the transfer certificate of } \\
\text { assets and liabilities, preparation of the } \\
\text { initial accounts. }\end{array}$ & $\begin{array}{l}\text { Analysis of current economic effects of the } \\
\text { reorganisation, provision of comparability of } \\
\text { financial statements, which act as a source of } \\
\text { information for analysis. }\end{array}$ \\
\hline
\end{tabular}

\section{Conclusions}

The effectiveness and expediency of the reorganisation can only be assessed after a certain period when comparative financial analysis of the reorganised companies, before and after the reorganisation has been done. However, ideally before reorganisation, it is necessary to draw up a financial model of the effects of the reorganisation, which can help resolve several problems: form a forecast of financial and economic indicators as a result of the organisation of the various options for reorganisation, to simulate the reporting of organisation in these cases, assess the possible legal, economic and other risks to budget expenditures for the reorganisation procedure, and establish a system of benchmarks to assess the achievements of the objectives and requirements of the owners of the results of the process reorganisation. Work on the compilation of the financial model of consequences of reorganisation will without doubt provide economic benefit, as will reduce the uncertainty of the economic situation of the company in the new organisational conditions. 


\section{References}

Order of the Ministry of Finance dated May 20, 2003 No. 44n "Ob utverzhdenii Metodicheskih ukazanij po formirovaniiu buhgalterskoj otchetnosti pri osuschestvlenii reorganizatsii organizatsij" ["On Approval of Guidelines for the formation of the financial statements in reorganisation of organisations"]// Bulleten' normativnyh aktov federal'nyh organov ispolnitel'noj vlasti [Bulletin of normative acts of institutions of the Federal Executive Authorities]. - 2003. - No. 401.

Baker, C.R., Biondi, Y., Zhang, Q., 2010. Disharmony in international accounting standards setting: The Chinese approach to accounting for business combinations // Critical Perspectives on Accounting, 21 (2), pp. 107-117.

Blaz y, R., Boughanmi, A., Deffains, B., Guigou, J.-D., 2012. Document Corporate governance and financial development: A study of the French case // Journal of Law and Economics, 33 (2), pp. 399-445

Camacho-Miñano, M.-D.-M., Campa, D., 2014. Integrity of financial information as a determinant of the outcome of a bankruptcy procedure // International Review of Law and Economics, 37, pp. 76-85.

Ghosal, V., 2013. Business Strategy and Firm Reorganization: Role of Changing Environmental Standards, Sustainable Business Initiatives and Global Market Conditions // Business Strategy and the Environment, Article in Press.

Huang, J.-C., Huang, C.-S., Lin, H.-C., 2013. Document Firm debt renegotiation, reorganization filing and bank relationships // International Finance, 16 (3), pp. 393-422

Bazarov, T.J., Eremin, B.L., 1998. Managing staff // Moscow Banks \& Exchanges Publishers Book-Publishing Association UNITY,

Markaryan, S.E., Snetkova, T. A., Khairullina, D. V. Administrative aspects of accounting organization. Russian experience and problems // Life Science Journal, 11(8), 2014. pp: 107-111.

Kaspina, R.G., Khapugina, L.S., Zakirov, E. A. Employment of activity-based costing in the process of company business model generation // Life Science Journal, 11 (8), 2014. pp: 356-359.

Needles Jr., B.E., Shigaev, A., Powers, M., Frigo, M. L. Operating characteristics of high performance companies: Strategic direction for management // Studies in Managerial and Financial Accounting, 28, 2014. pp: 25-51.

Bagautdinova N.G., Hadiullina G.N., Sarkin A.V., Pratchenko O.V. Typology of the regions with the account of level of influence of infrastructure facilities on the structure of economic areas // Asian Social Science, Volume 10, 28 2014, Pages 57-61.

Shumilin, P.Y., 2012. The reorganization of enterprises: specifics of accounting modelling Institute of Public Administration, Law and Innovative Technologies (IGUPIT) // Internet magazine NAUKOVEDENIE, No.4

Kaspina, R. G., Khapugina, L. S., Zakirov, E. A. Interrelation of Company's Business Model Structure and Information Disclosed in Management Reporting // Life Science Journal, 11 (12), 2014. pp: 778-780.

Pankov, V.V., Kazakov, N.A. Ekonomicheskij analiz [Economic analysis]. M.: Magistr, 2011, 624 pp.

Ismagilova G.N., Safiullin L.N., Bagautdinova N.G. Tourism development in region based on historical heritage. Life Science Journal 2014; 11(6s):363-367.

Klychova G.S., Zakirova A.R., Mukhamedzyanov K.Z., Faskhutdinova M.S. Management reporting and its use for information ensuring of agriculture organization management // Mediterranean Journal of Social Sciences vol. 5 № 24, November 2014, pp. 104-110

Sarkin, A.V., Bagautdinova, N.G., Averianov, B.A. Formulation of development strategies of machinery building complex enterprises and estimation of their implementation efficiency // World Applied Sciences Journal, 27(13), 2013, 170-173. 